\title{
Article \\ A Novel Bio-Fertilizer Produced by Prickly Ash Seeds with Biochar Addition Induces Soil Suppressiveness against Black Shank Disease on Tobacco
}

\author{
Xifen Zhang ${ }^{1,+}$, Yaochen Wang ${ }^{1,2,+}$, Xiaobin Han ${ }^{2,3, *}$, Jianyu Gou ${ }^{2,3}$, Wei Li ${ }^{4}$ and Chengsheng Zhang ${ }^{1, *} \mathbb{D}$ \\ 1 Tobacco Research Institute of Chinese Academy of Agricultural Sciences, Qingdao 266101, China; \\ zhangxifen0807@163.com (X.Z.); wangyaochen2020@163.com (Y.W.) \\ 2 Sinochem Agriculture Holdings, Beijing 100031, China; goujianyu2018@163.com \\ 3 Biological Organic Fertilizer Engineering Technology Center of China Tobacco, \\ Zunyi Branch of Guizhou Tobacco Company, Zunyi 563100, China \\ 4 College of Life, Yangtze University, Jingzhou 434200, China; weli@yangtzeu.edu.cn \\ * Correspondence: hanxiaobin2011@163.com (X.H.); zhangchengsheng@caas.cn (C.Z.); \\ Tel.: +86-0532-88702115 (C.Z.) \\ + These authors contributed equally to this work.
}

Citation: Zhang, X.; Wang, Y.; Han, X.; Gou, J.; Li, W.; Zhang, C. A Novel Bio-Fertilizer Produced by Prickly Ash Seeds with Biochar Addition Induces Soil Suppressiveness against Black Shank Disease on Tobacco. Appl. Sci. 2021, 11, 7261. https:// doi.org/10.3390/app11167261

Academic Editor: Manfred Lübken

Received: 23 July 2021

Accepted: 5 August 2021

Published: 6 August 2021

Publisher's Note: MDPI stays neutral with regard to jurisdictional claims in published maps and institutional affiliations.

Copyright: (c) 2021 by the authors. Licensee MDPI, Basel, Switzerland. This article is an open access article distributed under the terms and conditions of the Creative Commons Attribution (CC BY) license (https:// creativecommons.org/licenses/by/ $4.0 /)$.

\begin{abstract}
A novel bio-fertilizer, produced from prickly ash seeds (PAS), Bacillus subtilis and biochar, was evaluated for its disease-preventing potential on tobacco black shank caused by Phytophthora nicotianae. The results showed that biochar promoted the growth of Tpb55 in PAS and increased the $\mathrm{pH}$ of the organic fertilizer. The final concentration of B. subtilis could reach $1.7 \times 10^{10} \mathrm{cfu} \mathrm{g}^{-1}$ in the biological organic fertilizer (PBB) under the optimal medium under conditions of solid-state fermentation. PBB exhibited a strong fumigation effect on P. nicotianae, including inhibiting mycelium growth, reducing the disease severity and decreasing the pathogen population in rhizospheric soil. PBB treatment also could significantly increase the $\mathrm{pH}$ of acidified soil and improve soil nutrition content such as available $\mathrm{K}$, alkali hydrolysable $\mathrm{N}$ and organic carbon. High-throughput pyrosequencing of $16 \mathrm{~S}$ and $18 \mathrm{~S}$ rRNA genes revealed that $4 \%$ PBB addition in soil had significant effects on the diversity and richness of fungi but not on that of bacteria. The microbial community structure was also shifted after PBB treatment. Some potentially beneficial microbes such as Bacillus, Mucor, Cunninghamella, Chitinophaga and Phenylobacterium were enriched, while potential pathogen Fusarium was significantly decreased. In conclusion, the agricultural waste PAS combined with biochar can replace soybean as a source for the production of biocontrol B. subtilis Tpb55, and the novel bio-fertilizer could effectively control tobacco black shank by pathogen inhibition, soil nutrient improvement and shifting the rhizomicrobial community.
\end{abstract}

Keywords: Bacillus subtilis; biochar; biological control; prickly ash seeds; rhizosphere microorganisms

\section{Introduction}

Phytophthora nicotianae van Breda de Haan is a typical pathogen of soil-borne diseases that causes great economic losses in many important crops, including tobacco, tomato and citrus [1,2]. Tobacco is one of the most important cash crops in the world, but it is seriously damaged by black shank disease caused by P. nicotianae. Currently, amide pesticides such as metalaxyl and enylmorpholine are mainly used in tobacco black shank control, but this results in a series of problems, such as high pesticide residues, environmental pollution and pathogen resistance to fungicides [3]. Therefore, it is of great significance to develop efficient, safe and eco-friendly biocontrol measures.

Prickly ash (Zanthoxylum bungeanum, Rutaceae) is an important economic crop species in China, with an annual yield of 100 million hectares. In recent years, this species has received increasing attention due to its economic significance (important condiment and traditional Chinese medicine) and ecological value (ideal plant for afforestation in barren 
hills). Dried and peeled seeds of prickly ash (PAS) are the main by-products of the prickly ash industry. Nearly 1.5 billion kilograms of PAS are discarded as agricultural waste every year, resulting in resource waste and environmental pollution. In fact, PAS are rich in nutrients and bioactive components. Previous studies have shown the potential of PAS as a fumigant for controlling plant pathogens and root-knot nematodes [4,5]. However, it is unclear if PAS is a suitable material for bio-organic fertilizer (BOF) production.

It is well known that biochar addition can effectively prevent greenhouse gas emissions and nutrient loss during compost fermentation [6]. It also can regulate the growth of microorganisms and sequester carbon [7]. In addition, the application of an organic fertilizer with biochar could improve soil health, increase crop yields [8] and induce plant disease resistance [9]. We propose that biochar can also promote BOF production using PAS.

Currently, the use of BOF is considered to be an effective way to promote plant growth, inhibit disease occurrence and regulate soil microbial community structure [10]. For example, the combined use of Bacillus amyloliquefaciens W19 with organic fertilizer can decrease the incidence of Fusarium wilt in banana [11]. Our previous study revealed that PAS can inhibit a variety of microorganisms in the soil, but it increases Bacillus sp. [4], suggesting that it is feasible to produce Bacillus biocontrol agents by PAS. Therefore, in the current study, a novel BOF, named PBB, was produced from PAS with Bacillus subtilis Tpb55 inoculation and biochar addition, and its potential on tobacco black shank control was also evaluated.

\section{Materials and Methods}

\subsection{Materials}

Phytophthora nicotianae (Pn) strain JM01 was isolated and preserved by the Tobacco Research Institute of Chinese Academy of Agricultural Sciences. It was cultured in oatmeal agar medium (OA). Nicotiana tabacum 'Xiaohuangin 1025', which is susceptible to tobacco black shank disease, was chosen for the experiment. PAS of Zanthoxylum bungeanum, commonly called Dahongpao, was chosen for the experiment because it is the main cultivated variety of this species in Shandong Province. Biochar was prepared from rice husks by anoxic pyrolysis at $400{ }^{\circ} \mathrm{C}$. The air-dried moisture content (MAD), air-dried ash (ADA) and free radical volatiles (VAD) of this biochar were $3.16 \%(w / w), 14.34 \%(w / w)$ and $5.77 \%$ $(w / w)$, respectively.

\subsection{Optimization of PBB Production in Solid State Fermentation}

The orthogonal experiment was designed to optimize the medium formulation for solid-state fermentation. PAS, biochar and soybean powder were mixed in proportion (Table 1), placed into an Erlenmeyer flask $(100 \mathrm{~g} / 1 \mathrm{~L})$ and sterilized at $121^{\circ} \mathrm{C}$ for $20 \mathrm{~min}$. Then, B. subtilis Tpb55 suspension $\left(10^{8} \mathrm{cfu} / \mathrm{mL}\right)$ was inoculated $(2.5 \mathrm{~mL} / 100 \mathrm{~g})$, and the final water content of the medium was adjusted to $50 \%$ with sterile water. The fermentation was carried out at $28^{\circ} \mathrm{C}$ in the dark, and the flask was shaken once by hand every $12 \mathrm{~h}$. The $\mathrm{pH}$ and bacteria population were determined once a day and successively for one week. The key factors affecting the fermentation were obtained by orthogonal analysis of the data on the fourth day. Each treatment was repeated three times.

\subsection{Chemical Property Determination of $P B B$}

PBB samples were dried in an oven at $60{ }^{\circ} \mathrm{C}$ for $24 \mathrm{~h}$, and the ratio of the mass difference before and after drying to the mass of the sample before drying was the water content of the sample. The properties including $\mathrm{pH}, \mathrm{N}$ content, $\mathrm{C}$ sequestration content, available $\mathrm{P}$, available $\mathrm{K}$, ammonium $\mathrm{N}$ and nitrate $\mathrm{N}$ were determined according to the method described by Bao [12]. 
Table 1. The results of PAS fermentation with B. subtilis inoculation and biochar addition.

\begin{tabular}{|c|c|c|c|c|c|c|}
\hline \multirow{2}{*}{ Number } & \multicolumn{3}{|c|}{ Orthogonal Treatment Design } & \multirow{2}{*}{ pH (Day 0) } & \multirow{2}{*}{ pH (Day 7) } & \multirow{2}{*}{$\begin{array}{c}\text { Colony Density } \\
(\mathrm{cfu} / \mathrm{g})\end{array}$} \\
\hline & PAS a $^{(\%)}$ & $>\mathrm{SP}^{\mathrm{b}}(\%)$ & >Biochar (\%) & & & \\
\hline 1 & 50 & 15 & 15 & $6.33 \pm 0.00 \mathrm{e}$ & $6.82 \pm 0.01 \mathrm{~d}$ & $8 \times 10^{8} \mathrm{~d}$ \\
\hline 2 & 50 & 10 & 30 & $6.54 \pm 0.00 \mathrm{~b}$ & $6.93 \pm 0.01 b$ & $5 \times 10^{8} \mathrm{~d}$ \\
\hline 3 & 50 & 5 & 45 & $6.65 \pm 0.01 \mathrm{a}$ & $6.96 \pm 0.01 b$ & $1.7 \times 10^{10} \mathrm{a}$ \\
\hline 4 & 60 & 15 & 45 & $6.64 \pm 0.00 \mathrm{a}$ & $7.05 \pm 0.01 \mathrm{a}$ & $4.1 \times 10^{9} \mathrm{~b}$ \\
\hline 5 & 60 & 10 & 15 & $6.39 \pm 0.01 \mathrm{de}$ & $7.02 \pm 0.02 \mathrm{a}$ & $5.9 \times 10^{9} \mathrm{~b}$ \\
\hline 6 & 60 & 5 & 30 & $6.55 \pm 0.00 \mathrm{~b}$ & $6.93 \pm 0.00 b$ & $2.8 \times 10^{9} \mathrm{c}$ \\
\hline 7 & 70 & 15 & 30 & $6.52 \pm 0.00 \mathrm{bc}$ & $6.78 \pm 0.02 \mathrm{e}$ & $4.4 \times 10^{9} \mathrm{~b}$ \\
\hline 8 & 70 & 10 & 15 & $6.37 \pm 0.00 \mathrm{de}$ & $6.87 \pm 0.00 c$ & $2.4 \times 10^{9} \mathrm{c}$ \\
\hline 9 & 70 & 5 & 45 & $6.45 \pm 0.09 \mathrm{~cd}$ & $6.89 \pm 0.02 c$ & $1.6 \times 10^{10} \mathrm{a}$ \\
\hline 10 & 0 & 100 & 0 & $6.38 \pm 0.02 \mathrm{de}$ & $6.12 \pm 0.02 \mathrm{~g}$ & $1.4 \times 10^{10} \mathrm{a}$ \\
\hline 11 & 100 & 0 & 0 & $6.13 \pm 0.01 \mathrm{f}$ & $6.17 \pm 0.01 \mathrm{f}$ & $1.8 \times 10^{4} \mathrm{e}$ \\
\hline
\end{tabular}

${ }^{\mathrm{a}}$, prickly ash seeds; ${ }^{\mathrm{b}}$, soybean powder; ${ }^{\mathrm{c}}$, the colony density of Tpb55 on the fourth day of fermentation. Different letters within a column indicate significant differences among biochar-amended soils at $p<0.05$.

\subsection{Seed Germination Test for PBB}

We added distilled water to the PBB at a ratio of $10 \mathrm{~g}: 100 \mathrm{~mL}$, soaked the mixture for $3 \mathrm{~h}(150 \mathrm{rpm})$ and centrifuged it for $10 \mathrm{~min}(3000 \mathrm{rpm})$. We then poured $10 \mathrm{~mL}$ of supernatant into the culture dish with filter paper, placed 30 rape seeds on the filter paper and incubated them at $21^{\circ} \mathrm{C}$ for $48 \mathrm{~h}$. An equal volume of distilled water served as a control. We recorded the percentage of seed germination, and a germination rate of more than $90 \%$ was considered indicative of sufficient fermentation.

\subsection{The Fumigation Inhibition Effect of PBB on P. nicotianae}

A mycelial disc was inoculated with $P n$ at the center of an oat medium plate. The plate was inverted and $4 \mathrm{~g}$ of PBB was evenly spread to cover the culture dish. The plate was then sealed and cultured at $25{ }^{\circ} \mathrm{C}$ for four days. Treatment with no PBB addition served as a control. Each treatment was repeated three times.

\subsection{Pot Experiment}

The inocula of $P n$ were prepared according to the method in reference [4]. Briefly, millet was boiled until $2 / 3$ of the husks were broken, after which it was filtered through gauze, air-dried to approximately $40 \%$ water content and sterilized in a conical flask $\left(121^{\circ} \mathrm{C}\right.$, $20 \mathrm{~min})$. P. nicotianae was activated on the OA medium for seven days. The obtained fungus cakes were inoculated in a sterilized millet medium $(5 \mathrm{~mm}$ in diameter, three fungus cakes per bottle) with a hole punch and cultured at $26^{\circ} \mathrm{C}$ for 14 days.

The tested soil was collected from the tobacco field, and it was mixed with the $\mathrm{Pn}$ cultured by millet ( $4 \mathrm{~g}$ millet $/ 1 \mathrm{~kg}$ of soil) to obtain the diseased soil. There were four treatments in the experiments, i.e., 2\% PBB addition (PBB2), 4\% PBB addition (PBB4) and no PBB addition (control). Each pot was concealed with a plastic film for 10 days before transplanting. There were 15 replicates per treatment, and each treatment was repeated three times. The incidence of disease was assessed on the 15th day after inoculation, and the disease index, incidence rate and disease prevention effect were statistically analyzed [13].

\subsection{Real-Time Fluorescent Quantitative PCR of P. nicotianae}

On the 5th and 15th day after potting, rhizosphere soil of the tobacco seedlings was sampled, and the population of P. nicotianae was detected by real-time fluorescent quantitative PCR (RT qPCR). According to the $18 \mathrm{~S}$ rDNA gene sequence of $P$. nicotianae from the NCBI database, the following specific primers were designed for fluorescent quantitative PCR: SP: 5'-TGAAGAACGCTGCGAACTGC-3' , AP: 5'-CTGACATCTCCTCCACCGACTA$3^{\prime}$. The length of the amplified target fragment was $172 \mathrm{bp}$ [4]. DNA was extracted and purified from rhizosphere soil by a DNeasy ${ }^{\circledR}$ PowerSoil ${ }^{\circledR}$ Kit ((Qiagen, Hilden, Germany). 
The RT-qPCR reaction system had a total volume of $20 \mu \mathrm{L}$, consisting of $2.0 \mu \mathrm{L}$ cDNA, $10.0 \mu \mathrm{L}$ SYBR premix (Takara, Japan), $0.4 \mu \mathrm{L}$ SP $(10 \mu \mathrm{M} / \mu \mathrm{L}), 0.4 \mu \mathrm{L}$ AP $(10 \mu \mathrm{M} / \mu \mathrm{L}), 0.4 \mu \mathrm{L}$

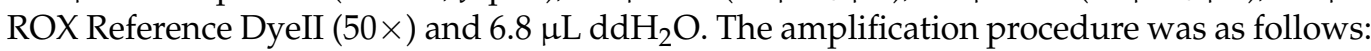
$94{ }^{\circ} \mathrm{C}$ for $5 \mathrm{~min}, 94{ }^{\circ} \mathrm{C}$ for $20 \mathrm{~s}, 65^{\circ} \mathrm{C}$ for $40 \mathrm{~s}$, and $72{ }^{\circ} \mathrm{C}$ for $40 \mathrm{~s}$, with a total of 40 cycles.

\subsection{Soil Chemical Property Determination}

On the 20th day after potting, soil chemical properties were determined according to the method described by Bao [12]. The content of alkaline hydrolyzed N (AN) in the soil was determined by the alkaline hydrolyzed diffusion method; the content of available $\mathrm{P}(\mathrm{AP})$ in the soil was determined by the $\mathrm{NaHCO}_{3}$ molybdenum-antimony anti-colorimetric method; the content of $\mathrm{AK}$ in the soil was determined by $\mathrm{NH}_{4} \mathrm{OAC}$ torch photometry; and the content of organic matter was determined by the potassium dichromate volumetric method.

\subsection{Microbial Diversity and Community of Rhizospheric Soil}

On the 15th day after treatment, the rhizospheric soils of tobacco seedlings treated with $4 \%$ PBB and no PBB addition were collected. The total soil DNA was amplified by $\mathrm{V} 3+\mathrm{V} 4$ regions of bacterial $16 \mathrm{~S}$ rRNA genes (515F and 806R) and ITS1 regions of fungal 18S rRNA genes (ITS5-1737F and ITS2-2043R). Operational taxonomic units (OTUs) are defined as sequences with more than $97 \%$ similarity. $\alpha$-diversity (Chao1, Shannon and ACE indexes) was calculated using Qiime (version 1.7.0), and $\beta$-diversity was analyzed by principal coordinate analysis (PCoA, Bray-Curtis).

\subsection{Statistical Analysis}

Microsoft Office Excel 2016 was used for data processing; IBM SPSS Statistics version 24.0 was used for variance and correlation analysis. The results of three replicates were expressed as means \pm standard deviations. Variance analysis and multiple comparisons were used for determining statistical significance, and $p<0.05$ was considered to indicate a significant difference. Principal coordinate analysis (PCoA) based on Bray-Curtis distance was used to compare the differences in bacterial and fungal community structure between the BOF and non-BOF treatment. Canonical correspondence analysis (CCA) was used to analyze the relationship between soil environmental factors and microbial community composition. PCoA and CCA were performed using R-2.15.3 for Windows.

\section{Results}

\subsection{PBB in Solid-State Fermentation}

The population of B. subtilis Tpb55 increased linearly in the first three days of fermentation and then logarithmically at the fourth day, resulting in saturation (Figure S1). Treatment 3 (10:1:9 of PAS: soybean cake: biochar) and treatment 9 (5:3:9 of PAS: soybean powder: biochar) showed the highest fermentation effect, with a colony density of $1.6-1.7 \times 10^{11} \mathrm{cfu} / \mathrm{g}$, which is equal to that of soybean cake powder alone (Table 1 ). The fermentation with PAS alone showed the lowest colony density of Tpb55, indicating that the fermentation process can be greatly influenced by biochar addition. This was further confirmed by the results of orthogonal analysis (Table S1), which identified biochar as the most significant influencing factor for fermentation $\left(p<0.0001, R^{2}=0.831\right)$.

During the fermentation, the $\mathrm{pH}$ value varied in the different treatments. On the fourth day, the $\mathrm{pH}$ values of treatments with biochar addition all increased significantly, with a $\mathrm{pH}$ closer to 7 (Table 1). No significant $\mathrm{pH}$ change was observed in samples treated with PAS fermentation alone, while the $\mathrm{pH}$ of soybean cake powder alone decreased significantly. These results indicated that biochar addition not only can promote fermentation but also increase the $\mathrm{pH}$ of fermentation. 


\subsection{Biochemical Characteristics of $P B B$}

Based on the fermentation formula optimization results, 10:1:9 of PAS: soybean cake: biochar was chosen as the fermentative material to produce PBB, and the fermentation time was 4 days. The germination rate of rape seeds treated with BOC extract was more than $90 \%$, indicating that the fermentation reached the primary maturities. The main biochemical characteristics of BOC were as follows: bacteria $1.7 \times 10^{11} \mathrm{cfu} / \mathrm{g}, \mathrm{pH} 6.97$, organic carbon $35.64 \%$, alkaline hydrolyzed N $11.2 \mathrm{~g} / \mathrm{kg}$, available P $21.69 \mathrm{mg} / \mathrm{kg}$ and available K $7574 \mathrm{mg} / \mathrm{kg}$.

\subsection{Inhibition Effect of PBB on P. nicotianae}

PBB showed a good fumigation effect on $P$. nicotianae mycelium growth, with an inhibition rate of $76.67 \%$ when treated with a volume of $4 \mathrm{~g} / \mathrm{dish}$. As shown in Figure 1, the hyphae fumigated with BOF were limited to a very small area, and aerial mycelia grew loosely, while the control grew vigorously and almost covered the entire dish.
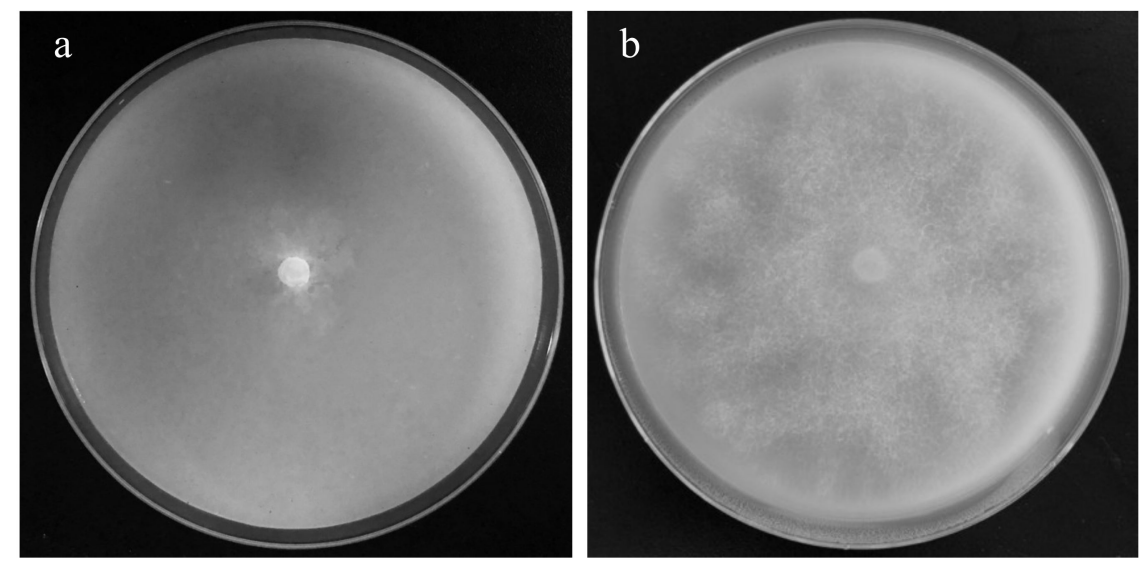

Figure 1. Fumigation effect of PBB on Phytophthora nicotianae. (a), 4 g/dish of PBB; (b), control.

As shown in Table 2, BOF can also influence the survival of $P n$ in soil. Compared to the control, DNA copies of $P n$ with $2 \%$ and $4 \%$ of BOF addition decreased $79.98 \%$ (PBB2) and $99.73 \%$ (PBB4) after five days of inoculation, respectively. Moreover, the inhibitory effect was sustained for 15 days. The inhibition rates of $2 \%$ and $4 \%$ BOF addition reached $98.94 \%$ and $99.76 \%$ on the fifteenth day.

Table 2. The effect of PBB treatment on P. nicotianae population and disease severity.

\begin{tabular}{cccc}
\hline \multirow{2}{*}{ Treatment } & \multicolumn{2}{c}{ DNA Copies of $\boldsymbol{P}$. nicotianae } & Disease Index \\
\cline { 2 - 4 } & Fifth Day & Fifteenth Day & Fifteenth Day \\
\hline PBB4 & $3494.31 \pm 85.77 \mathrm{~d}$ & $3346.10 \pm 95.92 \mathrm{~d}$ & $25.93 \pm 2.21 \mathrm{c}$ \\
PBB2 & $277,980.00 \pm 1346.43 \mathrm{c}$ & $14,717.10 \pm 174.78 \mathrm{~d}$ & $40.74 \pm 2.45 \mathrm{~b}$ \\
CK & $1,312,089.77 \pm 5765.04 \mathrm{a}$ & $1,388,622.37 \pm 12,616.09 \mathrm{a}$ & $63.89 \pm 2.07 \mathrm{a}$ \\
\hline
\end{tabular}

PBB4 and PBB2 represent $2 \%$ and $4 \%$ of bio-orgonic fertilizer addition, respectively; control, with no fertilizer addition. Different letters within a column indicate significant differences among biochar-amended soils at $p<0.05$.

\subsection{Prevention Effect of PBB Application on Tobacco Black Shank Disease}

The pot experiment showed that bio-organic fertilizer addition could alleviate the severity of tobacco black shank (Table 2). The disease index of treatment with BOF addition was lower than that in the control $(p<005)$. Moreover, $4 \%$ BOF addition showed a better preventive effect (59.41\%) than 2\% PBB addition (36.23\%). 


\subsection{Soil Chemical Properties Affected by PBB Addition}

As shown in Table 3, PBB application significantly increased the soil $\mathrm{pH}$, hydrolysable $\mathrm{N}$, available $\mathrm{K}$ and organic carbon, but it decreased the electrical conductivity compared to the control. The content of available $\mathrm{P}$ had no significant difference between treatment and control. Except for the increase in $\mathrm{pH}$ and available $\mathrm{K}$ content, the two BOF addition levels had no significant effect on the main soil nutrient supply, including available $\mathrm{P}$, hydrolysable $\mathrm{N}$ and organic matter.

Table 3. Effects of bio-organic fertilizer treatment on soil chemical properties.

\begin{tabular}{ccccccc}
\hline Treatment & pH & $\begin{array}{c}\text { Electrical } \\
\text { Conductivity }(\boldsymbol{\mu s} / \mathbf{c m})\end{array}$ & $\begin{array}{c}\text { Available } \mathbf{P} \\
(\mathbf{m g} / \mathbf{k g})\end{array}$ & $\begin{array}{c}\text { Available K } \\
(\mathbf{m g} / \mathbf{k g})\end{array}$ & $\begin{array}{c}\text { Hydrolysable N } \\
(\mathbf{m g} / \mathbf{k g})\end{array}$ & $\begin{array}{c}\text { Organic } \\
\text { Carbon }(\mathbf{g} / \mathbf{k g})\end{array}$ \\
\hline PBB4 & $6.79 \pm 0.02 \mathrm{a}$ & $677.00 \pm 4.36 \mathrm{c}$ & $72.76 \pm 1.41 \mathrm{~b}$ & $847.31 \pm 3.30 \mathrm{a}$ & $357.39 \pm 5.66 \mathrm{a}$ & $102.09 \pm 0.39 \mathrm{a}$ \\
PBB2 & $6.56 \pm 0.00 \mathrm{~b}$ & $793.00 \pm 12.17 \mathrm{~b}$ & $80.86 \pm 1.29 \mathrm{a}$ & $696.60 \pm 3.35 \mathrm{~b}$ & $301.52 \pm 38.82 \mathrm{~b}$ & $102.77 \pm 2.29 \mathrm{a}$ \\
CK & $6.19 \pm 0.03 \mathrm{c}$ & $1148.33 \pm 103.00 \mathrm{a}$ & $72.75 \pm 0.16 \mathrm{~b}$ & $462.22 \pm 3.31 \mathrm{c}$ & $288.63 \pm 10.90 \mathrm{~b}$ & $69.82 \pm 3.57 \mathrm{~b}$ \\
\hline
\end{tabular}

PBB4 represents $4 \%$ PBB addition; control, with no PBB addition. Different letters within a column indicate significant differences among biochar-amended soils at $p<0.05$.

\subsection{Microbial Diversity and Richness of Rhizospheric Soil}

The alpha diversity analysis revealed that the fungal diversity and richness index with PBB addition were lower than that of the control. No significant difference in bacterial diversity or richness index was observed between PBB and the control. These results indicated that fungi were more susceptible to PBB treatment than bacteria (Table 4).

Table 4. Operational taxonomic unit (OTU) richness and diversity indices of PBB treatment.

\begin{tabular}{ccccccccc}
\hline \multirow{2}{*}{ Treatment } & \multicolumn{4}{c}{ Fungal Community } & \multicolumn{4}{c}{ Bacterial Community } \\
\cline { 2 - 9 } & OTUs & Shannon & Chao1 & ACE & OTUs & Shannon & Chao1 & ACE \\
\hline Control & $207 \pm 11 \mathrm{a}$ & $2.78 \pm 0.09 \mathrm{a}$ & $235 \pm 12 \mathrm{a}$ & $237 \pm 11 \mathrm{a}$ & $1474 \pm 119 \mathrm{a}$ & $7.50 \pm 0.28 \mathrm{a}$ & $1612 \pm 110 \mathrm{a}$ & $1637 \pm 105 \mathrm{a}$ \\
PBB & $138 \pm 6 \mathrm{~b}$ & $2.53 \pm 0.07 \mathrm{~b}$ & $160 \pm 15 \mathrm{~b}$ & $177 \pm 20 \mathrm{~b}$ & $1362 \pm 38 \mathrm{ab}$ & $7.07 \pm 0.27 \mathrm{a}$ & $1517 \pm 24 \mathrm{a}$ & $1534 \pm 26 \mathrm{a}$ \\
\hline
\end{tabular}

PBB, $4 \%$ bio-organic fertilizer addition; control, no PBB addition; Different letters within a column indicate significant differences among biochar-amended soils at $p<0.05$.

\subsection{Effect of BOF Addition on Soil Microbial Community Structure}

Based on the T-test, the relative abundance of nine fungal genera and nine bacteria genera displayed significant differences between PPB treatment and the control (Table 5). PBB addition greatly increased the richness of Mucor, Rhizopus, Cunninghamella, Chitinophaga, Phenylobacterium and Bacillus. Nine genera were significantly decreased, including Penicillium, Trichoderma, Fusarium, Serendipita, Arthrobotrys, Helvella, Sphingomonas, Rhodanobacter and Gemmatimonas. In addition, the abundance of Bacillus in the treatment with PBB addition was significantly higher than that in the control (Table 5), which was consistent with the expected results of fermentation with B. subtilis Tpb55 inoculation.

PCoA showed the relationship between the compositions of all soil microbial communities (Figure 2). As shown in Figure 2, the four repeats randomly collected from each treatment had similar positions and were located in different quadrants. Among them, the bacterial community (Figure 2a) had a contribution of $63.81 \%$ on the abscissa and $34.43 \%$ on the ordinate, and the fungal community (Figure $2 b$ ) had a contribution value of $70.62 \%$ on the abscissa and $13.23 \%$ on the ordinate. The ADONIS test (Table S1) showed that the bacterial $\left(R^{2}=0.6162, p=0.03\right)$ and fungal $\left(R^{2}=0.6502, p=0.031\right)$ communities of PBB and control were significantly different. In summary, the composition of the soil microbial community changed significantly with the PBB application. 
Table 5. Genera with significant differences in relative abundance between BOF addition and control.

\begin{tabular}{cccc}
\hline \multirow{2}{*}{ Category } & Genus & \multicolumn{2}{c}{ Relative Abundance (\%) } \\
\cline { 2 - 3 } & Mucor & $\mathbf{4 \%}$ PBB Addition & Control \\
\hline Rhizopus & $28.8 \pm 3.60 \mathrm{a}$ & $2.83 \pm 0.55 \mathrm{~b}$ \\
Penicillium & $30.41 \pm 2.26 \mathrm{a}$ & $0.76 \pm 0.12 \mathrm{~b}$ \\
Trichoderma & $3.41 \pm 0.62 \mathrm{~b}$ & $23.13 \pm 1.27 \mathrm{a}$ \\
& Fusarium & $2.32 \pm 0.40 \mathrm{~b}$ & $6.94 \pm 0.66 \mathrm{a}$ \\
& Cunninghamella & $0.12 \pm 0.03 \mathrm{~b}$ & $0.79 \pm 0.08 \mathrm{a}$ \\
& Serendipita & $0.00 \pm 0.00 \mathrm{~b}$ & $0.00 \pm 0.01 \mathrm{~b}$ \\
& Arthrobotrys & $0.00 \pm 0.00 \mathrm{~b}$ & $0.11 \pm 0.01 \mathrm{a}$ \\
& Helvella & $0.00 \pm 0.001 \mathrm{~b}$ & $0.08 \pm 0.002 \mathrm{a}$ \\
& Chitinophaga & $11.77 \pm 0.03 \mathrm{a}$ & $1.95 \pm 0.39 \mathrm{~b}$ \\
Bphingomonas & $0.04 \pm 0.002 \mathrm{~b}$ & $0.09 \pm 0.003 \mathrm{a}$ \\
& Chitinophagaceae & $1.14 \pm 0.03 \mathrm{~b}$ & $0.06 \pm 0.01 \mathrm{a}$ \\
& Dyella & $2.54 \pm 0.01 \mathrm{a}$ & $1.93 \pm 0.12 \mathrm{~b}$ \\
& Rhodanobacter & $1.24 \pm 0.31 \mathrm{~b}$ & $4.24 \pm 0.43 \mathrm{a}$ \\
& Phenylobacterium & $3.51 \pm 0.73 \mathrm{a}$ & $1.64 \pm 0.175 \mathrm{~b}$ \\
& Bacillus & $4.07 \pm 0.43 \mathrm{a}$ & $2.86 \pm 0.24 \mathrm{~b}$ \\
& Gemmatimonas & $0.89 \pm 0.16 \mathrm{~b}$ & $2.81 \pm 0.72 \mathrm{a}$ \\
\hline
\end{tabular}

$\overline{\mathrm{PBB}}, 4 \%$ bio-organic fertilizer addition; control, no PBB addition; Different letters within a column indicate significant differences among biochar-amended soils at $p<0.05$.
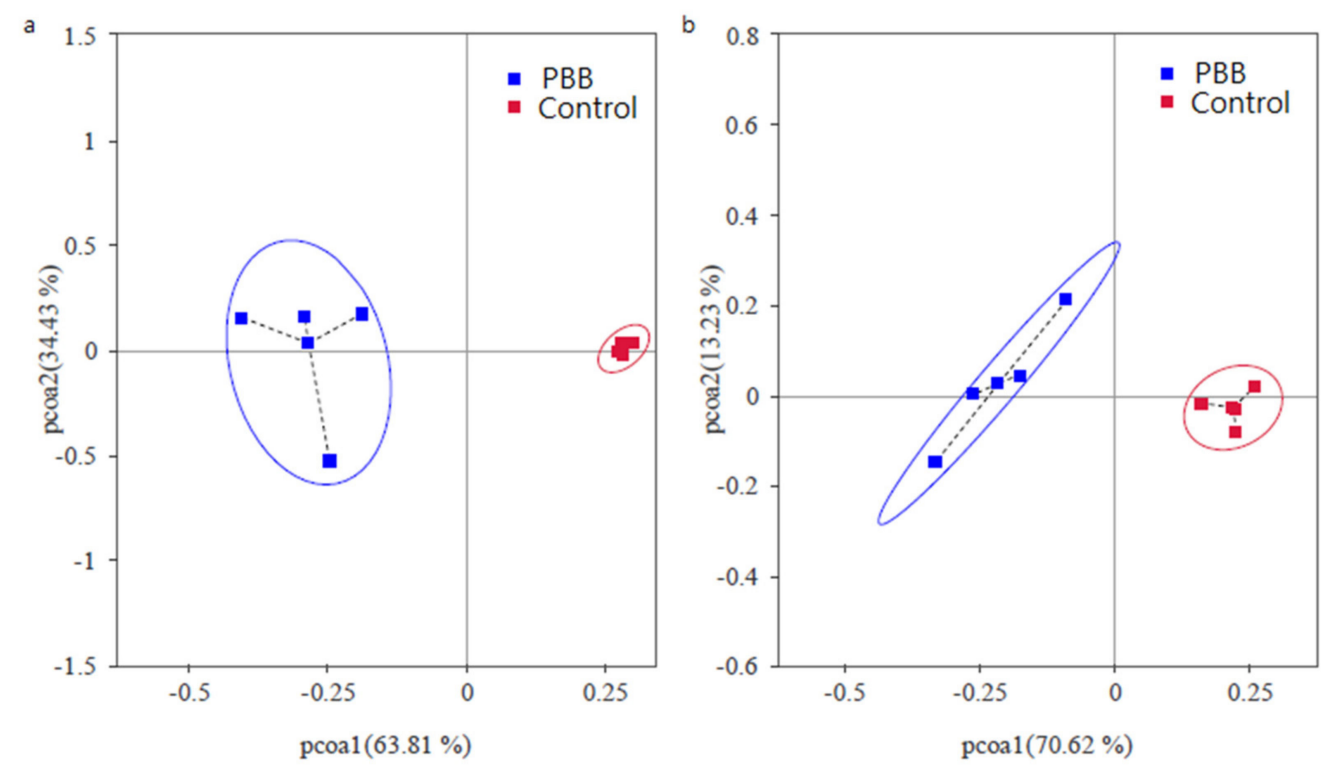

Figure 2. Principal coordinate analysis (PCoA) of soil fungal (a) and bacterial (b) communities based on Bray-Curtis distance. PBB represents $4 \%$ of PBB addition; control, with no PBB addition.

\subsection{Correlation between Soil Microbial Community and Soil Environmental Factors}

CCA analysis was used to further identify the soil characteristics that could contribute to microbial community variations affected by PBB addition. Both fungi and bacteria communities with BOF addition were well-separated from those in samples without PBB treatment (control). The length of the arrow represents the correlation. It can be seen from Figure 3 that the distribution of the fungi community from PBB samples was significantly positively correlated with $\mathrm{pH}, \mathrm{OC}, \mathrm{N}$ and $\mathrm{K}$, while that from non-PBB samples was related to EC (Figure 3a). A similar tendency was also found in the bacterial community (Figure 3b). At the genus level, Cunninghamella, Mucor, Rhizopus, Achromobacter, Chitinophaga, Phenylobacterium and Ochrobactrum were positively correlated with $\mathrm{pH}, \mathrm{OC}, \mathrm{TN}$ and AP, while the main influencing factor for Trichaoderma, Actinomucor, Fusasium, Penicillium, Arthrobotrys, Serendipita, Sphingomonas, Rhodanobacter and Gemmatimonas was EC (Figure 3). 


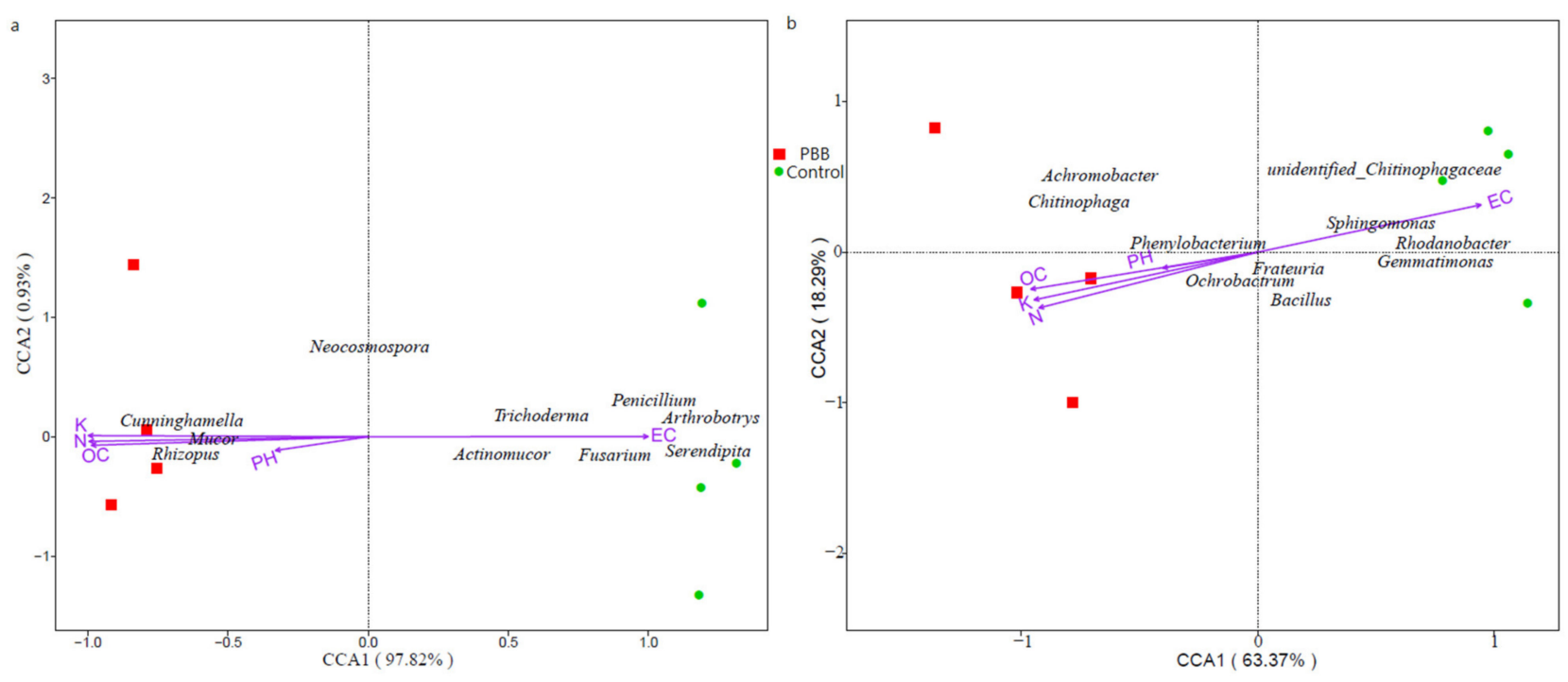

Figure 3. Canonical correspondence analysis (CCA) diagram illustrating the relationship between fungal (a) and bacterial (b) composition at genus level from different samples and environmental variables.

According to the partial Mantel test (Table S2), available potassium and EC had the most significant effect on soil fungi community structure $\left(R^{2}=0.9939, p<0.01\right.$ and $\left.R^{2}=0.9937, p=0.01\right)$, followed by AN $\left(R^{2}=0.9872, p=0.0225\right)$ and OC $\left(R^{2}=0.9719\right.$, $p=0.0285)$. The soil bacterial community was affected significantly by $\mathrm{AK}\left(\mathrm{R}^{2}=0.9833\right.$, $p<0.01)$ and total $\mathrm{N}\left(\mathrm{R}^{2}=0.9837, p<0.01\right)$, followed by OC and EC. $\mathrm{pH}$ showed no significant effect on either the fungal or bacterial community. Therefore, EC, available potassium, $\mathrm{TN}, \mathrm{OC}$ and EC may be important environmental factors affecting soil microorganisms.

\section{Discussion}

BOF produced by antagonistic microbes can effectively control soil-borne diseases of tobacco, cucumber, watermelon and other crops [14-16]. Agricultural straw, livestock manure and soybean meal are conventional raw materials for BOF production, while PAS is rarely used. The current study showed that using PAS as a substitute for soybean powder is feasible for B. subtilis Tpb55 production. The final number of bacteria in PBB was more than $10^{10} \mathrm{cfu} / \mathrm{mL}$ under the optimal PAS fermentation formula, which is equal to that produced by $100 \%$ of soybean powders. However, the growth of the Tpb55 strain was very low in PAS with no biochar addition, indicating that biochar has a great influence on the fermentation process. The promotion of biochar in microbial fermentation has been widely reported. The promotional effect can be associated with the pore structure and low density of biochar, which can increase the oxygen flux of the fermentation substrate $[6,17]$. It is especially important for the fermentation of PAS, harboring high fat content and low air permeability. Alleviating the $\mathrm{pH}$ decline may be another important role of biochar in fermentation. Additionally, the biochar also significantly increased the final $\mathrm{pH}$ of $\mathrm{PBB}$. To the best of our knowledge, this is the first report to produce BOF by PAS with biochar addition and B. subtilis inoculation.

$\mathrm{BOF}$ is considered to have advantages of both organic fertilizers and antagonistic microbes. Organic fertilizers can provide nutrients for antagonistic microbes and promote their colonization in soil $[18,19]$. These nutrients are also beneficial for plant growth $[20,21]$. Chen et al. [22] found that BOF fortified with Bacillus licheniformis X-1 and Bacillus methylotrophicus Z-1 showed a significant preventive effect against strawberry Fusarium wilt disease. Hafez et al. [23] reported that a BOF produced from spent grain waste with Azospirillium brasilense inoculation enhanced soil fertility and corn growth. Consitantly, PBB showed inhibitory activity against $P$. nicotianae, reduced the survival of pathogens in soil and decreased the disease severity of tobacco black shank. The soil $\mathrm{pH}, \mathrm{OC}, \mathrm{AN}$ and AK were also increased with PBB application. These results indicated for alkaline 
hydrolyzed $\mathrm{N}$ that pathogen inhibition and soil nutrient improvement were involved in the effects of PBB.

Soil microbial community structure not only affects plant growth but also has a close relationship with plant diseases $[24,25]$. The ability of BOF in the regulation of the soil microbial community has been widely reported, and they are considered an important disease prevention strategy [26,27]. Shen et al. [27] reported that BOF treatment shifted the soil microbial community and enhanced the populations of some beneficial microorganisms, such as Gemmatimonas and Sphingomonas. Zhao et al. [16] found that the application of BOF enriched with B. amyloliquefaciens increased the bacterial diversity but decreased the fungal diversity in soil, and populations of some potential beneficial taxa such as Firmicutes (Bacillus) and Basidiomycota were enhanced. In line with these results, PBB treatment reduced the richness and diversity of the fungal community but had no significant effect on that of bacteria. PBB application also altered the microbial structure in tobacco rhizospheric soil. As expected, the relative abundance of Bacillus increased with PBB treatment. In addition, some potential beneficial genera were also enriched, including Mucor, Rhizopus, Cunninghamella, Chitinophaga and Phenylobacterium [28-32]. Nine genera were significantly decreased, including Fusarium, which includes pathogens that can cause a variety of crop diseases $[15,16]$. These results indicate that organic fertilizer combined with biocontrol bacteria is more conducive to the regulation of the soil microecological environment, thus playing a dual role in promoting growth and preventing disease.

\section{Conclusions}

This study demonstrated that the agricultural waste PAS combined with biochar can replace soybean as a source for the production of biocontrol B. subtilis Tpb55. Pathogen inhibition, soil nutrient improvement and rhizomicrobial community shifting are included among the effects of the novel BOF for tobacco black shank control. However, the effect of $\mathrm{PBB}$ on B. subtilis Tpb55 colonization in rhizosphere soil needs further study.

Supplementary Materials: The following are available online at https:/ /www.mdpi.com/article/ 10.3390/app11167261/s1, Figure S1: The changes in bacteria number with different fermentation formulas, Table S1: ADONIS analysis using Bray-Curtis distance between PBB treatment and the control, Table S2: Partial Mantel test for whole OTUs of soil microbe versus environmental factors.

Author Contributions: Conceptualization, C.Z. and X.H.; investigation, X.Z. and Y.W.; writingoriginal draft preparation, X.Z.; funding acquisition and project administration, J.G.; methodology, W.L.; writing - review and editing, C.Z. All authors have read and agreed to the published version of the manuscript.

Funding: This research was funded by the China National Tobacco Corporation (110201902003) and the Science and Technology Project of Guizhou Tobacco Corporation (201809).

Conflicts of Interest: The authors declare no conflict of interest.

\section{References}

1. Kong, P.; Hong, C.; Jeffers, S.N.; Richardson, P.A. A Species-Specific Polymerase Chain Reaction Assay for Rapid Detection of Phytophthora nicotianae in Irrigation Water. Phytopathology 2003, 93, 822-831. [CrossRef]

2. Panabières, F.; Ali, G.S.; Allagui, M.B.; Dalio, R.J.D.; Gudmestad, N.C.; Kuhn, M.L.; Guha, R.S.; Schena, L.; Zam-pounis, A. Phytophthora nicotianae diseases worldwide: New knowledge of a long-recognised pathogen. Phytopathol. Mediterr. 2016, 55, 20-40. [CrossRef]

3. Wang, H.-C.; Chen, X.-J.; Cai, L.-T.; Cao, Y.; Lu, N.; Xia, H.-Q.; Wang, M.-S.; Shang, S.-H. Race distribution and distribution of sensitivities to mefenoxam among isolates of Phytophthora parasitica var. nicotianae in Guizhou province of China. Crop Prot. 2013, 52, 136-140. [CrossRef]

4. Wang, Y.; Liu, M.; Han, X.; Zheng, Y.; Chao, J.; Zhang, C.-S. Prickly Ash Seed Kernel: A New Bio-Fumigation Material Against Tobacco Black Shank. Agronomy 2020, 10, 770. [CrossRef]

5. Wang, X.; Shi, W.; Wang, J.; Gao, Z.; Li, S.; Wang, N.; Shi, Q. Control of Southern Root-knot Nematodes on Tomato and Regulation of Soil Bacterial Community by Biofumigation with Zanthoxylum bungeanum Seed. Hortic. Plant J. 2021, 7, 49-58. [CrossRef]

6. Guo, X.-X.; Liu, H.-T.; Zhang, J. The role of biochar in organic waste composting and soil improvement: A review. Waste Manag. 2020, 102, 884-899. [CrossRef] [PubMed] 
7. Yang, Y.; Awasthi, M.K.; Bao, H.; Bie, J.; Lei, S.; Lv, J. Exploring the microbial mechanisms of organic matter transformation during pig manure composting amended with bean dregs and biochar. Bioresour. Technol. 2020, 313, 123647. [CrossRef]

8. Mosharrof, M.; Uddin, K.; Sulaiman, M.; Mia, S.; Shamsuzzaman, S.; Haque, A. Combined Application of Biochar and Lime Increases Maize Yield and Accelerates Carbon Loss from an Acidic Soil. Agronomy 2021, 11, 1313. [CrossRef]

9. Jaiswal, A.K.; Frenkel, O.; Tsechansky, L.; Elad, Y.; Graber, E.R. Immobilization and deactivation of pathogenic enzymes and toxic metabolites by biochar: A possible mechanism involved in soilborne disease suppression. Soil Biol. Biochem. 2018, 121, 59-66. [CrossRef]

10. Xiong, W.; Guo, S.; Jousset, A.; Zhao, Q.; Wu, H.; Li, R.; Kowalchuk, G.A.; Shen, Q. Bio-fertilizer application induces soil suppressiveness against Fusarium wilt disease by reshaping the soil microbiome. Soil Biol. Biochem. 2017, 114, 238-247. [CrossRef]

11. Wang, B.; Shen, Z.; Zhang, F.; Raza, W.; Yuan, J.; Huang, R.; Ruan, Y.; Li, R.; Shen, Q. Bacillus amyloliquefaciens Strain W19 can Promote Growth and Yield and Suppress Fusarium Wilt in Banana under Greenhouse and Field Conditions. Pedosphere 2016, 26, 733-744. [CrossRef]

12. Bao, S. Soil Agrochemical Analysis; China Agriculture Press Co., Ltd.: Beijing, China, 2000.

13. Zhang, C.; Gao, J.; Han, T.; Tian, X.; Wang, F. Integrated control of tobacco black shank by combined use of riboflavin and Bacillus subtilis strain Tpb55. BioControl 2017, 62, 835-845. [CrossRef]

14. Liu, Y.; Shi, J.; Feng, Y.; Yang, X.; Li, X.; Shen, Q. Tobacco bacterial wilt can be biologically controlled by the application of antagonistic strains in combination with organic fertilizer. Biol. Fertil. Soils 2013, 49, 447-464. [CrossRef]

15. Qiu, M.; Zhang, R.; Xue, C.; Zhang, S.; Li, S.; Zhang, N.; Shen, Q. Application of bio-organic fertilizer can control Fusarium wilt of cucumber plants by regulating microbial community of rhizosphere soil. Biol. Fertil. Soils 2012, 48, 807-816. [CrossRef]

16. Zhao, J.; Wang, Y.; Liang, H.; Huang, J.; Chen, Z.; Nie, Y. The rhizosphere microbial community response to a bio-organic fertilizer: Finding the mechanisms behind the suppression of watermelon Fusarium wilt disease. Acta Physiol. Plant. 2018, 40, 17. [CrossRef]

17. Xiao, R.; Awasthi, M.K.; Li, R.; Park, J.; Pensky, S.M.; Wang, Q.; Wang, J.J.; Zhang, Z. Recent developments in biochar utilization as an additive in organic solid waste composting: A review. Bioresour. Technol. 2017, 246, 203-213. [CrossRef]

18. Huang, X.; Chen, L.; Ran, W.; Shen, Q.; Yang, X. Trichoderma harzianum strain SQR-T37 and its bio-organic fertilizer could control Rhizoctonia solani damping-off disease in cucumber seedlings mainly by the mycoparasitism. Appl. Microbiol. Biotechnol. 2011, 91, 741-755. [CrossRef] [PubMed]

19. Lang, J.; Hu, J.; Ran, W.; Xu, Y.; Shen, Q. Control of cotton Verticillium wilt and fungal diversity of rhizosphere soils by bio-organic fertilizer. Biol. Fertil. Soils 2012, 48, 191-203. [CrossRef]

20. Gao, C.; El-Sawah, A.M.; Ali, D.F.I.; Hamoud, Y.A.; Shaghaleh, H.; Sheteiwy, M.S. The Integration of Bio and Organic Fertilizers Improve Plant Growth, Grain Yield, Quality and Metabolism of Hybrid Maize (Zea mays L.). Agronomy 2020, 10, 319. [CrossRef]

21. Hussain, A.; Zahir, Z.A.; Ditta, A.; Tahir, M.U.; Ahmad, M.; Mumtaz, M.Z.; Hayat, K.; Hussain, S. Production and implication of bio-activated organic fertilizer enriched with zinc-solubilizing bacteria to boost up maize (Zea mays L.) Production and Biofortification under Two Cropping Seasons. Agronomy 2020, 10, 39. [CrossRef]

22. Chen, Y.; Xu, Y.; Zhou, T.; Akkaya, M.S.; Wang, L.; Li, S.; Li, X. Biocontrol of Fusarium wilt disease in strawberries using bioorganic fertilizer fortified with Bacillus licheniformis X-1 and Bacillus methylotrophicus Z-1. 3 Biotech 2020, 10, 80. [CrossRef]

23. Hafez, M.; Popov, A.I.; Rashad, M. Integrated use of bio-organic fertilizers for enhancing soil fertility-plant nutrition, germination status and initial growth of corn (Zea mays L.). Environ. Technol. Innov. 2021, 21, 101329. [CrossRef]

24. Faure, D.; Vereecke, D.; Leveau, J.H.J. Molecular communication in the rhizosphere. Plant Soil 2009, 321, 279-303. [CrossRef]

25. Li, X.-G.; Ding, C.-F.; Zhang, T.-L.; Wang, X.-X. Fungal pathogen accumulation at the expense of plant-beneficial fungi as a consequence of consecutive peanut monoculturing. Soil Biol. Biochem. 2014, 72, 11-18. [CrossRef]

26. Zheng, X.; Zhu, Y.; Wang, Z.; Zhang, H.; Chen, M.; Chen, Y.; Wang, J.; Liu, B. Effects of a novel bio-organic fertilizer on the composition of rhizobacterial communities and bacterial wilt outbreak in a continuously mono-cropped tomato field. Appl. Soil Ecol. 2020, 156, 103717. [CrossRef]

27. Shen, Z.; Wang, D.; Ruan, Y.; Xue, C.; Zhang, J.; Li, R.; Shen, Q. Deep 16S rRNA Pyrosequencing Reveals a Bacterial Community Associated with Banana Fusarium Wilt Disease Suppression Induced by Bio-Organic Fertilizer Application. PLoS ONE 2014, 9, e98420. [CrossRef]

28. Ziedan, E.-S.H.; Farrag, E.S.; Sahab, A. First record and preliminary evaluation ofMucor hiemalisas biocontrol agent on inflorescence brown rot incidence of date palm. Arch. Phytopathol. Plant Prot. 2013, 46, 617-626. [CrossRef]

29. Cong, Y.; Fan, H.; Ma, Q.; Lu, Y.; Xu, L.; Zhang, P.; Chen, K. Mixed culture fermentation between Rhizopus nigricans and Trichoderma pseudokoningii to control cucumber Fusarium wilt. Crop. Prot. 2019, 124, 104857. [CrossRef]

30. da Silva, M.N.; Pintado, M.M.; Sarmento, B.; Stamford, N.; Vasconcelos, M. A biofertilizer with diazotrophic bacteria and a filamentous fungus increases Pinus pinaster tolerance to the pinewood nematode (Bursaphelenchus xylophilus). Biol. Control. 2019, 132, 72-80. [CrossRef]

31. Sharma, S.; Kumar, S.; Khajuria, A.; Ohri, P.; Kaur, R.; Kaur, R. Biocontrol potential of chitinases produced by newly isolated Chitinophaga sp. S167. World J. Microbiol. Biotechnol. 2020, 36, 1-15. [CrossRef] [PubMed]

32. Ma, Y.; Rajkumar, M.; Oliveira, R.S.; Zhang, C.; Freitas, H. Potential of plant beneficial bacteria and arbuscular mycorrhizal fungi in phytoremediation of metal-contaminated saline soils. J. Hazard. Mater. 2019, 379, 120813. [CrossRef] [PubMed] 